UDK: 316.422(497.5)"1945/1990"

\title{
Modernizacija urbanoga života u Hrvatskoj kroz prizmu stambenih i komunalnih politika u razdoblju socijalizma*
}

\author{
MARIO BARA \\ Hrvatsko katoličko sveučilište, Odjel za sociologiju \\ Zagreb, Hrvatska \\ mario.bara@unicath.hr
}

U članku se upućuje na važnost nekih aspekata polustoljetne modernizacije u Hrvatskoj (1945. - 1990.) koja je donijela industrijsku transformaciju države i promjenu strukture stanovništva. Cilj je pokazati utjecaj javnih politika, tj. racionalizacije odlučivanja na primjerima modernizacijskih procesa u stambenim i komunalnim politikama. Paternalistička uloga države s jasnim nedostatkom pluralnosti bila je vidljiva u svakom segmentu gospodarskoga, političkoga i društvenoga života. Mjere za brzu gospodarsku i socijalnu transformaciju društva započele su još tijekom rata. Velike državne intervencije bile su naglašene u industrijalizaciji i urbanizaciji, koje su pratile migracije radne snage iz ruralnih u urbana područja. Zbog velikoga broja novih stanovnika gradova vlasti su posvećivale veliku pozornost stambenim i komunalnim politikama. Istovremeno ovaj rad smjera upozoriti na segmente političkoga odlučivanja koji do sada nisu bili promatrani kroz dimenziju javnih politika na primjeru nekih aspekata modernizacije urbanoga života u Hrvatskoj. U zaključku se upućuje na mogući interdisciplinarni okvir istraživanja problema javnih politika u povijesnoj dimenziji.

Ključne riječi: modernizacija; urbanizacija; javne politike; Hrvatska

\footnotetext{
Ovaj rad nastao je u okviru znanstvenoga projekta „Modernizacija urbanog života u Hrvatskoj kroz prizmu razvoja komunalne infrastrukture u 19. i 20. stoljeću”, koji financira Hrvatska zaklada za znanost.
} 


\section{Uvod}

Javne politike (engl. public policy), kao istraživačka orijentacija za analizu sadržaja i rezultata politika vlada, nisu bile prisutne u društvenim znanostima sve do druge polovine XX. stoljeća. ${ }^{1}$ Iako su postojali različiti pristupi analizama politika i prije razvoja javnih politika kao zasebne discipline unutar politologije, do promjene dolazi s pionirskim radom Harolda D. Lasswella. ${ }^{2}$ Novu istraživačku orijentaciju zamislio je kroz interdisciplinarni pristup različitih akademskih disciplina (politologije, sociologije, povijesti, prava, ekonomije i dr.) usmjerenih na racionalno rješavanje društvenih problema. ${ }^{3} \mathrm{U}$ početku je novi pristup imenovan pojmom policy, tj. policy orijentacije - kojim se određuju najvažniji izbori u javnom ili privatnom životu, a oslobođen je negativnih konotacija "političkoga” poput pristranosti i korupcije. ${ }^{4} \mathrm{Ta}$ je orijentacija uključivala: a) metode za istraživanje policy procesa, b) rezultate analize, c) nalaze disciplina koji čine najvažnije doprinose potrebama odlučivanja u danom vremenu. ${ }^{5}$ Kontekst nastanka orijentacije treba tražiti u povećanoj potrebi racionalizacije državnoga i političkoga odlučivanja nastaloj tijekom i nakon Drugoga svjetskog rata. Ideja racionalizacije odlučivanja logički se nastavlja na rad sociologa Maxa Webera, koji je uočio da rast industrijske civilizacije zahtijeva sve racionalnije oblike organizacije države i političkoga odlučivanja $\mathrm{u}$ upravljanju njezinim podsustavima poput trgovine, industrije i drugih. ${ }^{6}$ Procesi racionalizacije u odlučivanju postojali su i u zemljama sa socijalističkim sustavima, ali specifičan oblik ideološkoga odlučivanja nije doveo do podudarnosti s procesima koji su se paralelno odvijali u zapadnim demokracijama. ${ }^{\text {? }}$ Iako se disciplina javnih politika u Hrvatskoj počinje postupno razvijati tek krajem osamdesetih godina XX. stoljeća, to ne znači da se konture analize racionalnoga odlučivanja ne mogu prepoznati u znanstvenim publikacijama u

\footnotetext{
$1 \quad$ Hrvatski, kao i većina drugih jezika, nema posebne pojmove za engleske izraze policy i politics, nego obje riječi pokriva izraz „politika”. Kada je riječ o pojmu javne politike (public policy), on je nezaobilazan kao koncept u razumijevanju načina funkcioniranja i upravljanja društvenim sustavima. Pojam policy u početku se odnosio na cjelokupni sustav vlasti. S vremenom, jačanjem ideje racionalnoga dijela političkoga života, koji se odnosi na njegov sadržaj, dolazi do odvajanja od pojma politics te policy sadržajno postaje ono što političari žele postići. Rastom javnoga sektora tijekom XX. stoljeća taj se pojam dopunjavao, pa su navedene politike smatrane politikama za zajednicu i dobile su pridjev „javne”, što znači da se bave rješavanjem ekonomskih, socijalnih, demografskih, komunalnih, ekoloških i drugih mogućih problema s kojima se može suočiti neka politička zajednica.

LASSWELL, „The Policy Orientation”, 3-15.

Isto, 3 .

Isto, 5 .

Isto, 4

PETAK, „Komparativne javne politike”, 52.

ŽUPANOV, Od komunističkog pakla do divljeg kapitalizma, 112-113.
} 
ranijim razdobljima hrvatske povijesti, „pa se može govoriti o analizi politike bez jezika analize politika".

\section{Metodološki pristup}

Cilj je rada upozoriti na utjecaj javnih politika, tj. racionalizacije odlučivanja, na nekoliko dimenzija socijalističke modernizacije urbanih sredina u polustoljetnom razdoblju (1945. - 1990.). Primjeri poput stambene i komunalne izgradnje promatrat će se na najvećim hrvatskim regionalnim središtima. Među brojnim elementima modernizacije gradova ističu se novi oblici upravljanja prostorom, razni tehnički pothvati prepoznatljivi u postupnom uvođenju viših standarda gradnje u odnosu na prethodna razdoblja te prateće administrativne mjere, koje su sinergijski s tehničkim mjerama pozitivno utjecale na nagli demografski rast urbanih središta. Kulturna i simbolička dimenzija modernizacije imale su iznimno važnu ulogu u oblikovanju socijalističkoga društva, u kojem je socijalistički grad trebao svjedočiti ostvarenju idealnoga modela grada u kojem su se mogle zadovoljavati sve potrebe „radnih ljudi”. Osnovne metode koje su korištene jesu analiza relevantne literature i arhivskih izvora i njihovo razumijevanje u kontekstu vremena u kojem su nastali te komparativna metoda. Arhivsko gradivo koje svjedoči o radu različitih aktera u javnim politikama od partijskih, upravnih preko stručnih tijela i različitih zainteresiranih skupina za određene dimenzije politika, prije svega socijalnih, brojno je. Komparativna metoda korištena je u kontekstu i unutar pojmovnoga aparata javnih politika pri usporedbi djelovanja institucija Hrvatske sa saveznim institucijama i između državnih i nedržavnih aktera u javnim politikama. U radu ćemo na temelju relevantne literature i izvora pokazati važnost i strukture procesa odlučivanja, zatim nekoliko dimenzija socijalističke modernizacije gradova te na statističkim pokazateljima naglasiti njihovu pozitivnu korelaciju s promjenama u demografskim strukturama gradova u polustoljetnom razdoblju.

\section{Neke karakteristike hrvatskih modernizacija}

Racionalna kontrola čovjeka nad njegovom prirodnom i društvenom okolinom dovodi se u usku vezu sa stvaranjem novih društvenih struktura i društvenih institucija uz odgovarajuća sredstva za postizanje nekog kolektivnog cilja. Paralelnim djelovanjem kompleksnoga skupa procesa ostvaruje se zamjena jednostavnih društvenih struktura složenijim ili transformacija tradicionalnih društava u moderna. Sve složenija podjela rada jedan je od ključnih elemenata

8 PETKOVIĆ, „Javne politike u povijesti časopisa Politička misao”, 15. 
koji djeluju u prijelazu tradicionalnih u suvremena društva. Stvara se novi tip integracije i društvene solidarnosti, koju je Émile Durkheim nazvao organskom, a povezivao ju je uz industrijska društva. ${ }^{9}$ Max Weber izdvojio je proces racionalizacije i kontrole fizičkoga i društvenoga okruženja kao bitno obilježje modernih društava. ${ }^{10}$ Racionalizacija je, prema Weberu, vidljiva i u birokratski organiziranoj državi, koju vidi kao najefikasniji, najracionalniji društveni mehanizam za provođenje kolektivne društvene akcije. ${ }^{11}$ Talcott Parsons naglasak u nastanku modernosti stavlja na diferencijaciju središnjih funkcionalnih sustava: „privrede (prilagodba), politike (ostvarenje cilja), društvene zajednice (integracija) i kulture (održanje vrijednosnih obrazaca)." ${ }^{\prime 2}$ Navedeni procesi mogu biti inicirani na različite načine. Najčešće su pokrenuti promjenama u tehnologiji i(ili) vrijednostima, a glavni zaključak modernizacijske teorije pretpostavlja da zemlje u razvitku nužno trebaju preuzeti model društvenoga sustava i kulture modernoga Zapada ako se žele razvijati. ${ }^{13}$

U radu se priklanjamo pluralnom pristupu hrvatskim modernizacijama, koji je slijedom društvenih silnica nužno poprimao povijesno specifične obli$\mathrm{ke},{ }^{14}$ nasuprot linearnom zapadnom modelu razvoja ${ }^{15}$. Zbog svojih povijesnih i kulturnih uvjetovanosti Hrvatska pripada društvima koja su u modernizacijskim procesima imala umnogome različit razvojni put od zapadnih društava. Riječ je o višestrukom, nejedinstvenom fenomenu, s brojnim diskontinuitetima (ekonomskim, političkim, kulturnim). Diskontinuiteti su vidljivi u prijelazu iz tradicionalnoga, agrarnoga društva u građansko s razvijenim institucijama, zatim u industrijalizaciji, koja je imala obilježje zakašnjelosti u odnosu na neke druge zemlje s kojima se Hrvatska nalazila u istom političkom okviru do 1918., kao i specifičnom tipu industrijalizacije, u kojem je prevladavala prerađivačka proizvodnja orijentirana interesima i potrebama drugih središta političke i ekonomske moći izvan Hrvatske. ${ }^{16}$ Ti su se čimbenici ogledali među ostalim i u sporijem razvitku gradova. Gradovi su, unatoč postupnom demografskom rastu, bili još nedovoljno industrijski i infrastrukturno kapacitirani da budu snažniji generator razvoja tadašnjega društva. ${ }^{17}$ Diskontinuitete hrvatske modernizacije dobro opisuje tvrdnja da ju je obilježavalo „više modernizacijskih pokušaja (modela) jasno odijeljenih strukturnim

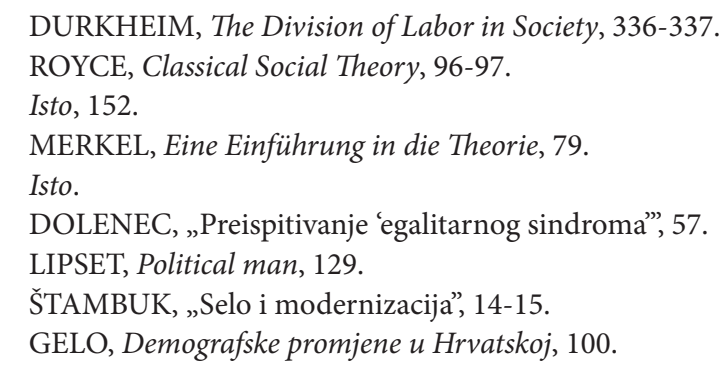


rezovima" ${ }^{18}$ Za razumijevanje hrvatskih modernizacijskih procesa nužna je njihova kontekstualizacija unutar povijesnih i geopolitičkih datosti u kojima su se odvijali. Može se izdvojiti nekoliko čimbenika: a) prirodni, poput geografske različitosti panonskoga, mediteranskoga i dinarskoga područja, b) ekonomski kroz gospodarsku neujednačenost te c) društveno-politički, poput upravno-političke i teritorijalne razjedinjenosti Hrvatske, nedostatka državne samostalnosti unutar višenacionalnih država kojih je bila sastavnim dijelom tijekom XIX. i XX. stoljeća, uz ratove i promjene političkih sustava koje su pratile promjene modernizacijskih obrazaca.

Procese modernizacije u Hrvatskoj sociološki nastoji objasniti Ivan Rogić. ${ }^{19}$ Izdvaja tri procesa pod kojima podrazumijeva modernizaciju: industrijalizaciju, urbanizaciju i birokratizaciju, a unutar industrijalizacije tehničku modernizaciju apostrofira ključnim elementom za ostvarenje ukupne modernizacije društva. ${ }^{20}$ Modernizacije u Hrvatskoj dijeli na tri razdoblja: a) prvu modernizaciju ograničava na razdoblje od 1868. do 1945., b) druga modernizacija odvijala se u razdoblju socijalizma od 1945. do 1990. i c) treća modernizacija, koja je započela 1991. godine. Karakteristika prve modernizacije periferan je položaj i manjak državne samostalnosti Hrvatske u višenacionalnim monarhijama. Periferija je bila marginalizirana uz nedostatak temeljne infrastrukture. U središtima višenacionalnih država bile su koncentrirane politička i ekonomska moć, koje su diktirale dinamiku razvoja. Spora dinamika razvoja bila je vidljiva u dominantnoj agrarnoj strukturi stanovništva do polovine XX. stoljeća. Oni oblici modernizacije koji su postojali bili su obilježeni privatnom inicijativom i privatnim kapitalom te neravnomjernim razvojem sjevernih dijelova Hrvatske i Dalmacije, odnosno Istre. ${ }^{21}$ Skromni oblici industrije koji su postojali bili su prerađivačko-agrarna i šumska industrija. ${ }^{22}$

Druga ili socijalistička modernizacija, koja je apostrofirana u ovom radu, započinje nakon Drugoga svjetskog rata. Najvažnija karakteristika polustoljetne modernizacije jest da je vođena političkim sredstvima u prekidu starih društvenih struktura, bez pluralnosti društva i privatne ekonomske inicijative. Ne negirajući postojanje nekih elemenata modernizacije unutar socijalističkoga sustava, razni su autori nastojali upozoriti na nedostatke takva modela, pa su takav tip modernizacije opisivali "modernizacijom bez modernosti” „paradoksalnom modernizacijom” jer se ostvarivala u proklamiranom „samo-

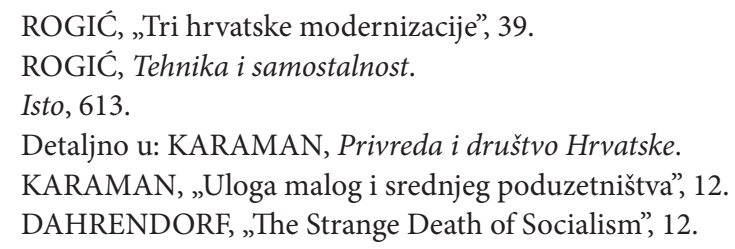


upravljačkom modelu”24 ili pristupom koji cjelokupnu socijalističku modernizaciju shvaća kao veliku „povijesnu aberaciju na putu modernizacije”, pa se može govoriti o „polumodernizaciji” ${ }^{25}$ Kada je riječ o karakteru jugoslavenske države od 1945. do 1990., ona je bila „poseban slučaj” i u tom je razdoblju imala elemente totalitarne države ${ }^{26}$, ali i pojedine specifičnosti koje se odnose na elemente tržišnoga sustava, napose od 1965. godine. Unatoč tim elementima tržište nikad nije bilo prepušteno potpuno slobodnom razvoju. ${ }^{27}$

\section{Politike i javne politike}

U zapadnim liberalnim demokracijama u drugoj polovini XX. stoljeća posebna se pozornost posvetila razumijevanju procesa upravljanja kao središnjem konceptu analize politika. Daljnji razvoj discipline vidljiv je i u pojmovnom određenju područja istraživanja i metodološkoga pristupa. ${ }^{28}$ Prema nekim definicijama, javne su politike „zbroj vladinih aktivnosti, koje djeluju izravno ili kroz agencije, te imaju utjecaj na život građana” ili najkraće „što god vlade odlučile činiti ili ne činiti” ${ }^{29}$ Pod time se i nečinjenje, odnosno ignoriranje nekog društvenog problema može smatrati javnom politikom. Iako nije postignut konsenzus o zajedničkoj definiciji što su javne politike, postoje zajednički elementi definicija: a) javne politike javljaju se kao odgovor na neku vrstu problema, b) donose se za javnost, c) orijentirane su na postizanje cilja ili željenoga stanja (što je dobro za zajednicu) i d) politike donose vlade iako ideje i inicijative mogu doći izvan vlade i njezinih tijela. ${ }^{30}$

Relevantna literatura s područja javnih politika razlikuje dvije dimenzije stvaranja politika, odnosno ključnih aktera. Akteri se mogu podijeliti na okomitu i vodoravnu dimenziju, odnosno na formalne (državne) i neformalne (nedržavne) aktere. ${ }^{31}$ Okomita dimenzija fokusira se na prenošenje legitimnih odluka od vrha prema nižim razinama, podređenim dužnosnicima koji ih provode u djelo. Unutar okomite dimenzije ističu se moć legitimnih vlasti, racionalan izbor i instrumentalno djelovanje. U vodoravnoj dimenziji vidljivo je strukturiranje djelovanja unutar širokoga kruga sudionika, mogućih

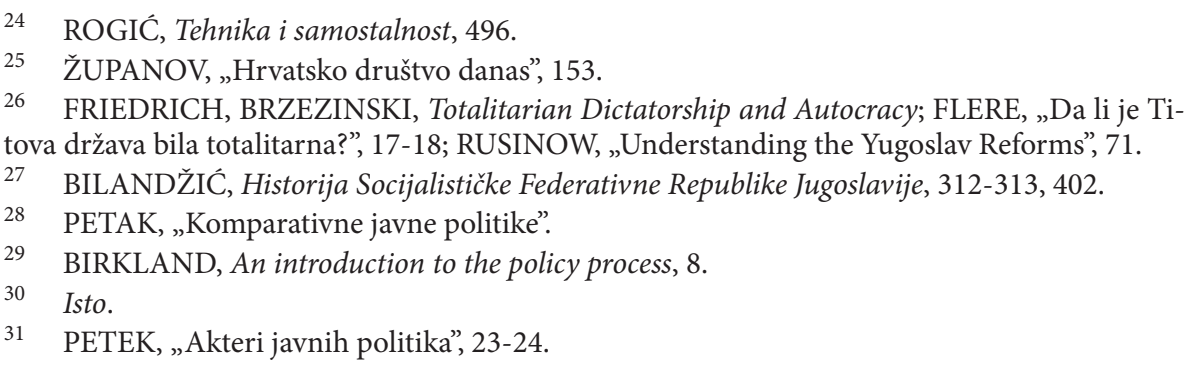


zainteresiranih strana u različitim organizacijama, izvan strogo definirane hijerarhijske vlasti. ${ }^{32}$

Još tijekom rata donesena je odluka o izgradnji Jugoslavije na federativnom principu. Pristupilo se i formiranju jasne okomite dimenzije javnih politika, a vodoravna dimenzija razvijat će se naknadno. Zemaljsko antifašističko vijeće narodnog oslobođenja Hrvatske (ZAVNOH) obnašalo je sva prava koja pripadaju Federalnoj Državi Hrvatskoj ako ta prava nisu ulazila u nadležnost njegova Predsjedništva ili Narodne vlade Hrvatske. ${ }^{33}$ Proklamirano je da sva vlast pripada narodu preko njegovih izabranih zastupnika u narodnooslobodilačkim odborima, temeljnim organima narodne vlasti, na svim razinama od seoskih, općinskih i gradskih, preko kotarskih, okružnih, oblasnih i pokrajinskih skupština do ZAVNOH-a. ${ }^{34}$

Hrvatska je kao i ostale republike Socijalističke Federativne Republike Jugoslavije svoje uređenje temeljila na uređenju Jugoslavije. Tijela republičke uprave slijedila su organizaciju savezne uprave, uz iznimku saveznih organa pod čijom su nadležnosti bili poslovi saveznoga značaja. ${ }^{35} \mathrm{U}$ smislu javnih politika i ključnih aktera važan je aspekt bilo ukidanje stranačkoga pluralizma uz uspostavu monopola Komunističke partije Jugoslavije (KPJ), odnosno Komunističke partije Hrvatske (KPH), koje su imale stvarnu vlast u odlučivanju. U podjeli dimenzija stvaranja politika KPJ i KPH po političkoj bi moći spadale među aktere okomite dimenzije odlučivanja, tj. formalne, državne aktere. Prvim poslijeratnim Ustavom, donesenim 18. siječnja 1947., u Narodnoj Republici Hrvatskoj kao najviša tijela državne vlasti određeni su Sabor i Prezidijum Sabora, Vlada je definirana kao najviše izvršno i upravno tijelo državne vlasti, a Vrhovni sud bio je najviše tijelo sudbene vlasti. ${ }^{36}$ Vodoravnu dimenziju javnih politika u promatranome razdoblju činili su dionici javnih politika (engl. policy stakeholders). Pod njima se podrazumijevaju „pojedinci, skupine i organizacije koje imaju interes u pojedinoj politici tako da utječu ili mogu utjecati na određenu politiku ili pak da ta politika utječe na njihov društveni položaj". ${ }^{37}$ Pojam dionici u javnim politikama odnosi se samo na one aktere koji pripadaju neformalnoj, nedržavnoj dimenziji javnih politika. ${ }^{38} \mathrm{Zbog}$ monopolističke uloge u odlučivanju i utjecaja u svim sferama života koje su imale KPJ i KPH tek je manji dio aktera doista zadovoljavao osnovne kriterije

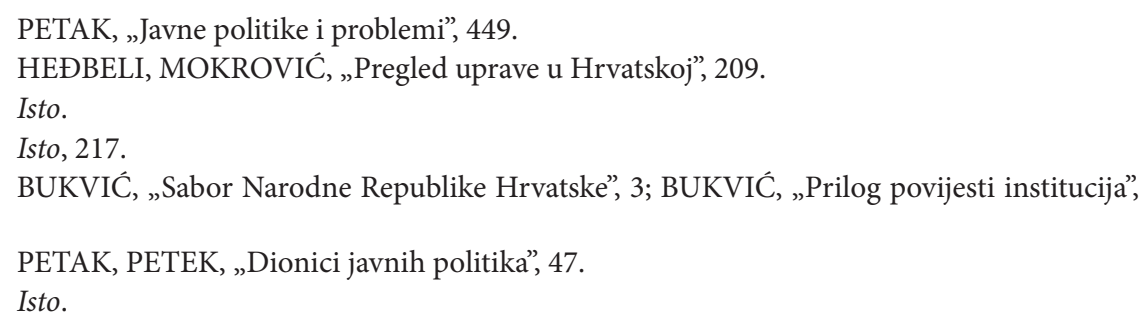


da bi bili svrstani u dionike javnih politika, odnosno neformalne, nedržavne dimenzije javnih politika. Oni se mogu prepoznati u pojedinim društvenim skupinama (npr. studenti, radništvo, poljoprivrednici, mladi, žene), određenim profesionalnim strukovnim udrugama (npr. Savez urbanista Hrvatske, Savez arhitekata Hrvatske), zavodima, istraživačkim organizacijama i sveučilištima, drugim društvenim akterima poput $\mathrm{Crkve}^{39}$, medija, napose nakon „krhkog procesa njihove liberalizacije koji se odvijao do početka 1970-ih” ", ali i pojedincima i njihovu odnosu prema društveno-političkim organizacijama. Međutim, kada je riječ o pojedincima, građanima, oni su imali najmanji utjecaj na javne politike, napose u kontekstu političkoga monopola partijske vlasti, a njihovo djelovanje prvenstveno je bilo usmjereno na ostvarivanje osobnih prava, ponajprije socijalnih. ${ }^{41}$ Dio neformalnih aktera sastavljen od sveučilišnih profesora, istraživača, novinara, savjetnika, administrativnih stručnjaka i stručnjaka javne uprave bio je važan element jugoslavenske politike, ali s ograničenom spremnošću političara na suradnju i slušanje. ${ }^{42}$

Država se reformirala i restrukturirala pod utjecajem unutarnjih i vanjskih čimbenika te je u skladu s njima osnivala odgovarajuća tijela i institucije. Tako se mogu pratiti promjene u broju nadležnih ministarstva, poslije sekretarijata, osnivanju savjetodavnih tijela, republičkih zavoda, komiteta, administrativno-teritorijalnih jedinica.$^{43}$ Najčešće se za analizu rada institucija od 1945. do 1990. koriste manja podrazdoblja koja su podudarna s ustavnim razdobljima. Riječ je o razdobljima triju ustava Jugoslavije i jednoga ustavnog zakona, unutar kojih su promjene ustava donosile preobrazbu političkoga sustava i državnih institucija. Promjene se mogu pratiti od prvoga ustavnog razdoblja, koje traje „od Ustava 1946. i traje do Ustavnog zakona iz 1953., drugo do Ustava iz 1963. godine, treće do Ustava iz 1974. (s amandmanima 1967., 1968. i 1971.), a četvrto od 1974. (s amandmanima 1981., 1986., 1989. i 1990.) do Ustava Republike Hrvatske iz 1990. godine". ${ }^{44}$ Posebna uloga bila je namijenjena mjesnim narodnim odborima, koji su trebali svjedočiti funkcioniranje novih oblika ekonomske i teritorijalno-političke samouprave. Trebali su osigurati demokratsko sudjelovanje građana u sustavu odlučivanja o društveno-ekonomskim procesima u cilju umanjivanja centralizma i birokratskih tendencija pri upravljanju. Od njih se očekivalo da kao lokalna središta vlasti

\footnotetext{
39 Primjerice pastoralni rad Katoličke crkve s iseljenicima u europskim i prekooceanskim zemljama, čime je Crkva, iskoristivši spore reakcije državnih tijela, postala akterom u migracijskim politikama. Usp. BASKIN, „Politički proces i policy zajednice”, 49.

40 MIHALJEVIĆ, „Liberalizacija i razvoj medija”, 241.

41 Detaljno o odnosu građana i vlasti u: MIHALJEVIĆ, Komunizam i čovjek, 120-336.

42 BASKIN, „Politički proces i policy zajednice”, 44.

43 HEĐBELI, MOKROVIĆ, „Pregled uprave u Hrvatskoj”, 209-217.

44 ŠTAMBUK-ŠKALIĆ, „Prilog poznavanju institucija”, 83-84.
} 
obavljaju važne gospodarske, kulturne, prosvjetne, socijalne, zdravstvene i političke funkcije. ${ }^{45} \mathrm{U}$ stvarnosti su proklamirani „organi narodnog samoupravljanja” simulirali demokraciju u totalitarnom ozračju. ${ }^{46} \mathrm{U}$ izvorima kao i literaturi iz socijalističkoga razdoblja koja problematizira odnos države i društva, probleme upravljanja, društvenoga vlasništva i komunalne izgradnje primjetna je opterećenost ideološkim izrazima, „marksističkog metajezika”, unutar kojega se ipak povremeno javlja senzibilitet za javne politike. ${ }^{47}$ Položaj nedržavnih aktera uglavnom je opisivan kroz ovisnost o zahtjevima političkih elita. Slabljenjem hijerarhijske kontrole osamdesetih godina mogla se uočiti veća samostalnost aktera u javnim politikama, pa se na primjeru Jugoslavije moglo potvrditi da takav odnos nije tipičan „samo za kapitalističke, liberalno-demokratske zemlje" ${ }^{48}$ Prostor za sudjelovanje nedržavnih aktera bio je najmanji ili nepostojeći u nekim od klasičnih državnih resora poput vanjske politike, sigurnosnih politika, obrambene politike, politika javnoga reda i mira i drugih iz uskoga djelokruga države, a najviše je prostora postojalo u onim politikama koje političke elite nisu percipirale kao potencijalnu ugrozu autoritetu Partije i države. Riječ je ponajviše o mogućnosti sudjelovanja stručnjaka različitih profesija i profesionalnih organizacija u socijalnim politikama koje su uključivale politike urbanizacije i prostornoga uređenja, stambene, komunalne i zdravstvene politike.

Neki aspekti modernizacije urbanih sredina kroz prizmu javnih politika

Poslijeratna socijalistička modernizacija obilježena je paternalističkom ulogom države koja je na sebe preuzela velike ovlasti uz najavu brze gospodarske i socijalne transformacije društva te poboljšanja kvalitete života. ${ }^{49} \mathrm{Teh}$ nički napredak uz transformaciju društvenih i ekonomskih odnosa država je najbrže mogla promovirati u urbanim prostorima, gdje je uz tehničke provodila kulturne i simboličke zahvate. Urbana središta trebala su postati novi, socijalistički gradovi, idealni gradovi za zadovoljenje svih potreba za klasu „urbanih radnika kao nositelja razvoja novog socijalističkog društva”. ${ }^{50}$ To su trebali postati sadržajno i vizualno novi tipovi gradova za ostvarenje „socijalističkog načina života", u kojima bi se velika pozornost usmjerila na kulturu i rekreaciju uz elementarno pravo radnika na grad, rad i stanovanje. ${ }^{51}$

\footnotetext{
BILANDŽIĆ, Historija Socijalističke Federativne Republike Jugoslavije, 229.

ROGIĆ, Tehnika i samostalnost, 496.

PETKOVIĆ, „Javne politike u povijesti časopisa Politička misao”, 15.

BASKIN, „Politički proces i policy zajednice”, 45.

PULJIZ, „Socijalna politika”, 20-21.

KOROV, „Zajednička ili zasebna?”, 52.

WAKEMAN, „Was There an Ideal Socialist City?”, 106.
} 


\section{Stambene politike}

Jedno od temeljnih ljudskih prava jest pravo na stanovanje. Brojna istraživanja pokazala su višestruka značenja doma „kao središta obiteljskog života, mjesta za povlačenje, za sigurnost, opuštenost, slobodu i neovisnost; mjesta za samoizražavanje i socijalni status; kao mjesto privatnosti, kontinuiteta i stalnosti, u smislu financijske imovine, te sredstva za rad i slobodno vrijeme" ${ }^{52}$ Područje stanovanja često se nalazi u nekom obliku intervencije države radi izgradnje učinkovitoga modela stambene politike. Stambene politike skup su izravnih i neizravnih mjera države u području stanovanja koje su povezane s gospodarskom politikom, politikom urbanizacije te u velikoj mjeri utječu na regionalni razvoj.

Neposredno nakon Drugoga svjetskog rata Hrvatska je imala nisku kvalitetu stanovanja, čemu je uz ratna razaranja pridonio i skroman standard dostignut u godinama neposredno prije početka rata. Poslijeratno razdoblje bilo je obilježeno kroničnim nedostatkom stambenih površina. Uz nedostatak stambenih jedinica izazvan ratnim razaranjima, na dodatnu potražnju za stanovima utjecala je od države inicirana intenzivna industrijalizacija, koja je posljedično potaknula doseljavanje novoga stanovništva u urbana središta. Država se, kao i u ostalim socijalnim politikama, ubrzo nametnula kao ključni akter u reguliranju stambenih prilika, pa se Ustavom Federativne Narodne Republike Jugoslavije (FNRJ) iz 1946. obvezala na brigu o stambenim prilikama (čl. 20.). Stambeni fond popunjavao se nacionaliziranim i konfisciranim stanovima, a dodatno je uveden model sustanarstva. Odredbom o maksimumu prostorija definiran je prostor kojim je mogla raspolagati jedna obitelj, a višak se oduzimao i davao na korištenje onima koji nisu posjedovali stambeni prostor. ${ }^{53}$

Uz državu se javljaju i akteri u stambenim politikama izvan stroge državne hijerarhije. Radi osiguravanja zemljišta za izgradnju stambenih zgrada i izvođenje pripadajućih građevinskih radova (poput gradnje putova, vodovoda, kanalizacije, nogostupa, uređenja okoliša i dr.) osnivane su stambene zadruge. ${ }^{54} \mathrm{Zbog}$ racionalizacije i tipizacije stambenih zgrada željelo se osigurati višekratnu primjenu postojećih projekata na različitim lokacijama, pa je već 1946. raspisan savezni natječaj za tipske stambene zgrade. Suprotno očekivanjima, natječaj nije ostvario željeni utjecaj na projektantsku praksu. ${ }^{55}$ Što se tiče drugih potencijalnih aktera u stambenim politikama, prostora za stručnu kritiku

52 SOMERVILLE, „The social construction of home”, 227-228.

53 KLEMPIĆ, „Razvoj stambenih naselja Splita”, 96; ALFIREVIĆ, SIMONOVIĆ-ALFIREVIĆ, „Urban housing experiments”, 4-5.

54 SR-AJ-41-SPK, kut. 536, „Nacrt pravila Stambene zadruge Zagreb. Zagreb, 6. III. 1947.”

55 DOMLJAN, „Poslijeratna arhitektura u Hrvatskoj”, 6. 
bilo je malo, napose za javno osporavanje. Tako su struke poput urbanista, arhitekata, građevinara i drugih postale dio mehanizma za raskidanje veza s ostatcima staroga društvenog sustava. ${ }^{56} \mathrm{U}$ prvim poslijeratnim godinama stambena arhitektura bila je obilježena funkcijom temeljne potrebe za stambenim prostorom, ali bila je vidljiva i njezina kulturna i simbolička dimenzija: „Pred očima društva, koje se bližilo ostvarenju nove kvalitete socijalističkog humaniteta, lebdjela je vizija nove arhitekture koja će, samim tim što proizlazi iz njega i služi tom društvu, imati u odnosu na arhitekturu kapitalističkih zemalja novu i humaniju dimenziju." ${ }^{7}$

Gradilo se uz minimalne troškove s ograničenim sredstvima za financiranje zahtjevnih stambenih projekata. Bitan moment bilo je i nepostojanje velikih građevinskih poduzeća s potrebnom tehnikom i kvalificiranim radnicima. Gradnja je u to vrijeme imala izraziti biljeg prosječnosti, bez naglašene estetske dimenzije, i sa snažnom ideološkom komponentom usmjerenom na zadovoljavanje tek osnovnih stambenih i tehničkih standarda. Vidljivo je to i iz narativa samih predstavnika struke, pa Andre Mohorovičić, arhitekt i povjesničar umjetnosti, kaže: „Suvremena monumentalnost proizlazi iz snage radnih masa, a ne iz distance klasnih suprotnosti, i prema tome moraju i oblici suvremene arhitekture biti novi, proizašli iz nove stvarnosti društvenih odnosa i izraženi novom statikom i novim materijalom." ${ }^{58}$

Petogodišnjim planom Narodne Republike Hrvatske od 1947. do 1951. postavljen je imperativ poboljšanja stambenih prilika. S petogodišnjim planom koincidira početak izgradnje planskih naselja za radnike. Najboljim modelom za rješavanje stambenih problema smatralo se kolektivno stanovanje. Planirana je izgradnja 15 milijuna kvadratnih metara novih stambenih površina i milijun kvadratnih metara školskih. ${ }^{59}$ Masovnom proizvodnjom montažnih stambenih zgrada s tipiziranim i standardiziranim građevnim dijelovima nastojalo se ostvariti zadane planove. ${ }^{60}$ Unatoč tomu, stambena izgradnja nije uspijevala pratiti sve veću potražnju za stanovima, koja je dodatno povećavana ruralno-urbanim migracijama. Svojom političkom ulogom država je ujedno bila i najveći investitor, a privatno vlasništvo nad nekretninama nastojalo se svesti na minimum. ${ }^{61}$

Šezdesetih godina zapažao se sve veći udio građana kao aktera u stambenoj izgradnji. Postojalo je uvjerenje među građanima da je individualna

\footnotetext{
FRANKOVIĆ, „Urbanističko planiranje Zagreba”, 86.

DOMLJAN, „Poslijeratna arhitektura u Hrvatskoj”, 5.

Isto, 6.

KRIŽIĆ ROBAN, „Obilježja modernosti”, 58.

DOMLJAN, „Poslijeratna arhitektura u Hrvatskoj”, 5.

MAROEVIĆ, „Hrvatska arhitektura pedesetih”, 141.
} 
gradnja najjeftinija. Individualna gradnja u Jugoslaviji 1964. iznosila je 57,6 \% ukupne stambene izgradnje, 1965. 62,4 \%, a 1967. 64,7 \%. ${ }^{62}$ Takva se izgradnja poticala i nekim praksama poput kredita radnih organizacija, davanjem zemljišta i sl., a nedovoljno se zamjenjivala racionalnijim oblicima poput prethodno uređenih zemljišta, zgrada u nizu, racionalne parcelacije i sl. ${ }^{63}$ Važno je naglasiti da se znatan dio individualne gradnje podizao bespravno. Prema jednom od istraživanja za potrebe saveznih tijela, bespravna gradnja bila je zastupljena u 47 \% individualne gradnje u uzorku od 70 anketiranih gradova. ${ }^{64}$ Među razlozima raširene pojave bespravne gradnje ističu se nedostatna razrađenost urbanističkih planova i loša zemljišna politika za takvu izgradnju, propusti u lokalnim propisima, neorganiziranost općinskih komunalnih i inspekcijskih službi, a na individualnoj razini nemogućnost građana da samostalno riješe probleme stanovanja ili da podnesu potrebne troškove legalne gradnje. ${ }^{65}$ Fenomen se najviše javljao u novim naseljima na rubovima grada. U odnosu na zemlje u razvoju, gdje je bespravna gradnja uglavnom nastajala na uzurpiranom zemljištu, u Hrvatskoj su vlasnici bespravno izgrađenih objekata u pravilu bili i vlasnici zemljišta na kojima su objekti građeni. ${ }^{66} \mathrm{~S}$ problemom bespravne gradnje Split se suočio već pedesetih godina ${ }^{67}$, ali i Zadar ${ }^{68}$, Zagreb ${ }^{69}$ te nešto manje drugi gradovi. Postojeće trendove s individualnom gradnjom $\mathrm{u}$ kasnijim se godinama nastojalo destimulirati niskim stanarinama za korištenje stanova u društvenom vlasništvu. ${ }^{70}$ Stambene politike kao i uloge subjekata u socijalističkom samoupravnom društvu doživjele su brojne promjene. Početna uloga državnoga distribuiranja postupno je napuštana preko raznih posrednika, a u svojem završnom razdoblju poprimala je sve više samoupravnih oblika. Javili su se i drugi nedržavni akteri, poput tržišta, koje istina nije bilo prepušteno potpuno slobodnom formiranju, ali je također imalo važnu ulogu. ${ }^{71}$ Poduzeća su dodatno preuzela ulogu u stambenom zbrinjavanju vlastitih radnika. ${ }^{72}$

\footnotetext{
62 SR-AJ-130-SIV, kut. 749, Savezna skupština, Komisija za urbanizam i uređenje prostora, „Osnove politike urbanizacije i prostornog uređenja - teze. Januar 1969.", str. 6.

63 SR-AJ-41-SPK, kut. 536, „O mogućnosti stanbene izgradnje u 1950. godini na individualnoj osnovi", str. 1.

64 SR-AJ-130-SIV, kut. 749, Savezna skupština, Komisija za urbanizam i uređenje prostora, „Osnove politike urbanizacije i prostornog uređenja - teze. Januar 1969.”, str. 6.

65 Isto.

66 KLEMPIĆ, „Razvoj stambenih naselja Splita”, 96.

67 HR-DAST-119-URBS, „Slobodan Bjelajac, Bespravna stambena izgradnja u Splitu, 1970.”

68 GALJER, GALIĆ, „Kultura stanovanja u Zadru”, 320-321.

69 SEFERAGIĆ, „Stanovanje kao pokazatelj socijalne segregacije”, 70.

70 SEFERAGIĆ, Kvaliteta života i nova stambena naselja, 77.

71 Isto, 49 .

72 BEŽOVAN, „Stanovanje i stambena politika”, 339.
} 
Državni akteri poticali su masovnu i jeftinu izgradnju za kolektivno stanovanje. Da se kvantitetom riješi stambeno pitanje što većega broja stanovnika, država je poticala snižavanje troškova gradnje te tako utjecala na oblikovanje novih stambenih naselja sa skromnom opremljenošću i minimalnom kvadraturom. ${ }^{73} \mathrm{U}$ pravilu su takvi stanovi bili građeni u velikim zgradama, koje su bile važna simbolička manifestacija socijalističke urbanizacije. ${ }^{74}$ Bilo ih je i u manjim gradovima, koji su komunalnom decentralizacijom osiguravali financijska sredstva za njihovu izgradnju. Time su manja urbana središta također ostvarivala prepoznatljive simbole socijalističkoga prosperiteta. ${ }^{75}$ Najintenzivnija gradnja nebodera odvijala se pedesetih i šezdesetih, a nakon sedamdesetih godina takav tip izgradnje postupno stagnira. ${ }^{76}$ Primjerice, u spomenutom razdoblju Zagrebu je dobio stambeni superblok Siget, kolokvijalno imenovan Super Andrija (građen 1972. - 1973.), i stambenu zgradu u naselju Travno kolokvijalnoga naziva Mamutica (građena 1974. - 1975.). ${ }^{77}$ Rijeka se ističe stambenim neboderima smještenim na Podmurvicama (1965. - 1968.), Kozali (1969. - 1973.) i Rastočinama (1973.). U riječkom naselju Turnić izgrađeni su (1975.) i svojedobno najviši (96 m) stambeni neboderi u Jugoslaviji, koji su kolokvijalno nazivani „neboderi smrti”. Drugi gradovi također su imali intenzivnu stambenu izgradnju. U Osijeku je tijekom socijalističkoga razdoblja izgrađeno više od dvadeset novih stambenih naselja s 503 stambene zgrade i 13610 stanova. Ključna su dva desetljeća (1960. -1980.) kada je izgrađeno gotovo 90 \% svih stanova, s najvećim udjelom dvosobnih. ${ }^{78}$ Split je također rastao prostorno i populacijski. Dio grada Split II, građen od 1945. do 1965., imao je približno 14000 stanova. Novi dio grada za 30000 stanovnika gradio se nakon 1968. na 330 ha gradske površine u smjeru Omiša, za koji se ustalio naziv Split III. ${ }^{79}$

Unatoč proklamiranim središnjim vrijednostima u društvu u vrijeme socijalizma bilo je različitih oblika nejednakosti. Rezidencijalna segregacija bila je primjetna u svim velikim socijalističkim gradovima na temelju položaja u političkoj hijerarhiji, zaposlenja ili obrazovanja.$^{80}$ Visoka kvaliteta stanovanja ostvarivana je za vojnu, policijsku i državnu elitu uz istovremeno ostvarivanje minimuma stanovanja za ostalu populaciju. ${ }^{81}$ Jačanjem ekonomske krize

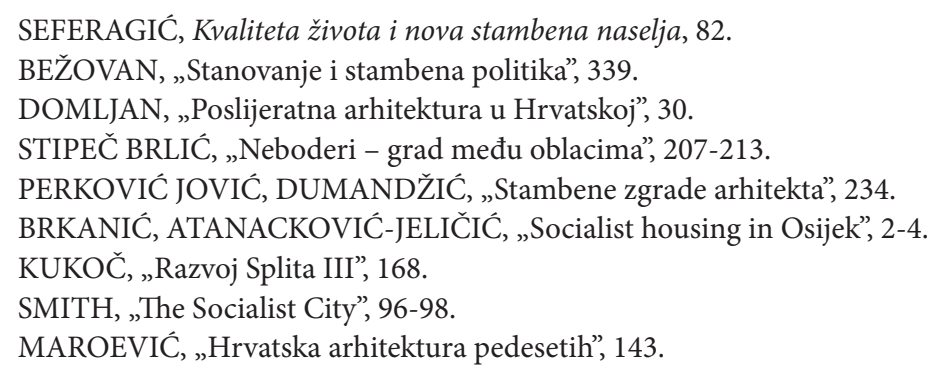


osamdesetih godina u zemlji postupno je slabjela imigracija u gradove, što se odrazilo na postupnu stabilizaciju stambenoga fonda. Razdoblje karakterizira koncept „društvenoga stana”. Preko društvenoga vlasništva promovirana je socijalna pravednost. ${ }^{82}$ Stanovi u društvenom vlasništvu činili su četvrtinu svih stanova, a bili su najzastupljeniji u najvećim gradovima. Primjerice, $\mathrm{u}$ Zagrebu su pretkraj socijalističkoga poretka stanovi u društvenom vlasništvu činili $45 \%$ tadašnjega gradskoga stambenog fonda. ${ }^{83}$ Stambeno tržište formirano je osamdesetih godina djelomično na temelju zakona ponude i potražnje. U promatranom razdoblju uz formalne, državne aktere u stambenim politikama profilirao se i dio nedržavnih aktera, ponajviše iz urbanističke i arhitektonske struke, građevinarstva, stambenih zadruga, tržišta i samih građana. Stjecanje stanova uvelike je ovisilo o ekonomskoj snazi pojedinih poduzeća, pa je i taj moment utjecao na društvene razlike.

\section{Komunalne politike}

Komunalne politike onaj su dio javnih politika koji se odnosi na funkcioniranje života u lokalnim zajednicama, tj. zadovoljenje javnih potreba građana. Državna intervencija u ubrzanoj industrijalizaciji i urbanizaciji potaknula je migracije i porast urbanoga stanovništva, posljedično i veliku razliku između potreba za stambenim objektima i usklađenosti s postojećom urbanom i komunalnom infrastrukturom. Dodatne posljedice na sve aspekte javnih politika ostavila je ekonomska situacija nakon razlaza sa Sovjetskim Savezom 1948. godine. Državni akteri i pripadajuće institucije (usp. grafikon 1) nastojali su odrediti mogućnosti bolje, brže i ekonomičnije izgradnje. ${ }^{84}$ Posebno je bila pogođena stambena i komunalna izgradnja zbog nedostatka građevinske opreme, napose sanitarnih uređaja. Nedostatke se pokušavalo nadomjestiti najrazličitijim modelima, niskim normativima, smanjenjem troškova u komunalnoj izgradnji poput vezivanja više stambenih jedinica na jedan sanitarni čvor. ${ }^{85}$ Eksperimentalni pokušaji nisu davali željene rezultate, imali su negativne posljedice, te su zbog malih financijskih ušteda ubrzo napušteni. ${ }^{86}$

FRANIĆ, KORLAET, VRANIĆ, „Prilog analizi stambenih”, 199.

BEŽOVAN, „Stanovanje i stambena politika”, 339.

SR-AJ-60-KLPKP, kut. 4, „Pretsedniku privrednog saveta Vlade FNRJ drugu Borisu Kidriču”, 22. 4. 1950. Primjerice, razmatrale su se mogućnosti zamjene metalnih cijevi (napose od čelika i željeza) za vodovod i kanalizaciju drvenima i keramičkima.

85 MAROEVIĆ, „Hrvatska arhitektura pedesetih”, 143.

86 DOMLJAN, „Poslijeratna arhitektura u Hrvatskoj”, 12. 
Grafikon 1. Prikaz linija povezanosti unutar aktera u komunalnim politikama - Savjet za komunalne poslove i lokalnu privredu Vlade FNRJ ${ }^{87}$

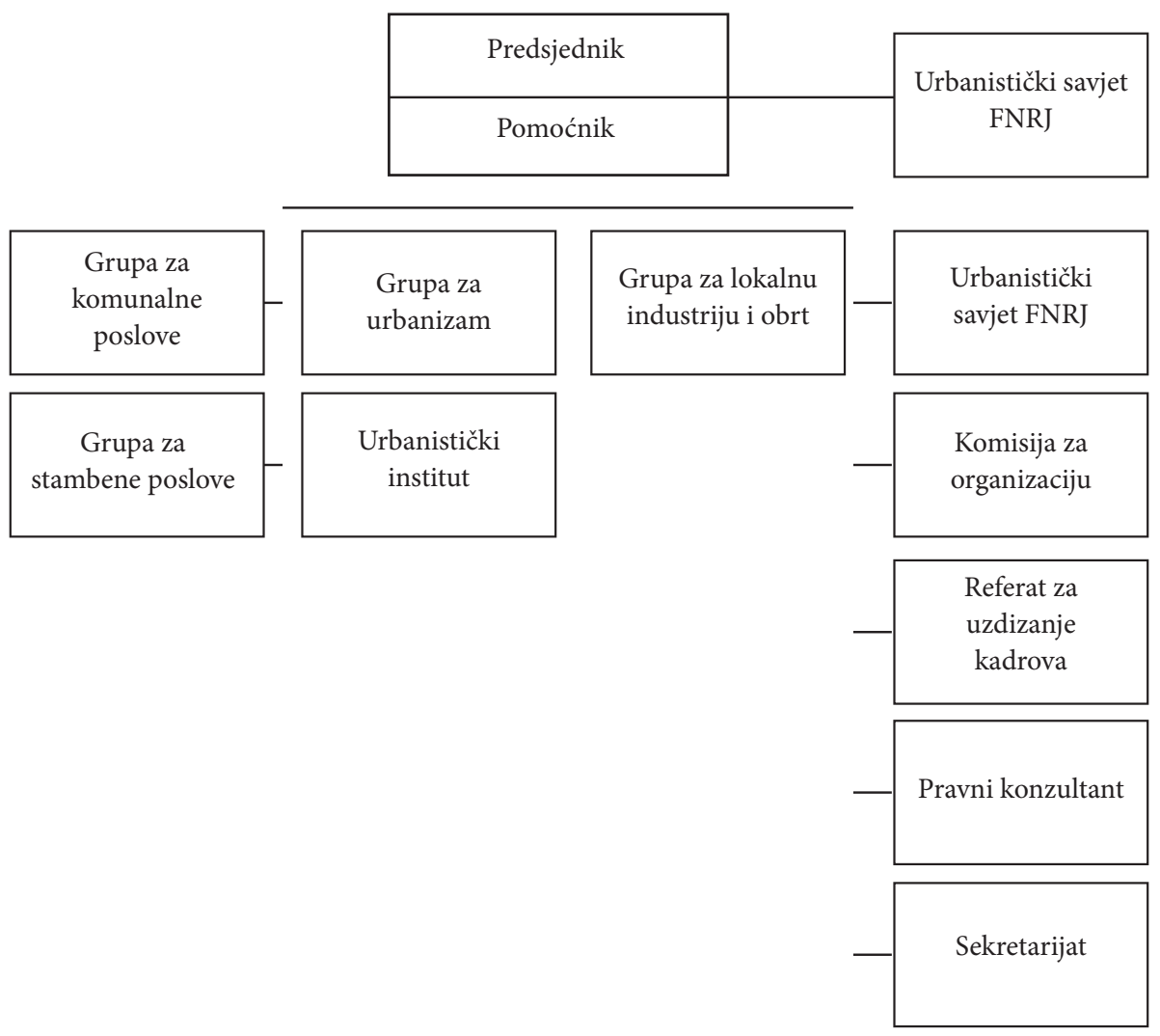

Uz državne institucije, važnu ulogu u komunalnim politikama imale su mjesne zajednice. Njihova reforma zahtijevala je da im praktična djelatnost bude društveno korisna, uz zadovoljenje što većega broja životnih potreba građana i najracionalnije korištenje radnih i materijalnih potencijala građana, radnih organizacija i općina. Prepoznate su lokalne specifičnosti i znanja za sadržaj rada mjesnih zajednica, naime da njihov sadržaj djelovanja ne smije biti univerzalan nego karakterističan za svaku specifičnu sredinu, s naglaskom na samoorganiziranje građana. ${ }^{88} \mathrm{U}$ komunalne politike uključivani su i neformalni akteri kao predstavnici različitih struka (arhitekti, urbanisti, geo-

87 SR-AJ-41-SPK, kut. 561, „Predlog za organizaciju komunalne delatnosti, urbanizma i lokalne privrede", str. 7.

88 SR-AJ-130-SIV, kut. 749, „Konstatacije i predlozi XVI skupštine Stalne konferencije gradova Jugoslavije u Mostaru 9, 10, i 11 Novembra 1966. godine o mestu i ulozi mesnih zajednica u našem društveno-političkom sistemu”, str. 1-2. 
grafi, sociolozi, tehnički stručnjaci, statističari i dr.) u Savjetu za urbanizam i komunalne poslove. ${ }^{89}$

Pritisak na postojeću komunalnu infrastrukturu nije se smanjivao, pa se nametao imperativ u izgradnji prometnica, novih škola, vrtića, potrebi elektrifikacije, plinofikacije, izgradnje vodovoda i kanalizacijskih sustava, kulturnih sadržaja, napose podizanja objekata masovne kulture i društvenoga standarda, uređenja okoliša i drugih sadržaja. U praksi je veliki broj popratnih objekata nakon izgradnje stambenih jedinica ostajao nedovršen godinama. Planski izgrađivana naselja udaljena od gradskih središta, bez dobre prometne povezanosti, bila su bez potrebnih dječjih ustanova, uslužnih lokala i prateće komunalne infrastrukture. ${ }^{90}$

Uvidjelo se da su neophodna izdvajanja dodatnih materijalnih sredstava za izgradnju škola i drugih sadržaja u novim naseljima. U tom je smislu jedan od zaključaka skupštine Stalne konferencije gradova Jugoslavije 1953. u Mariboru da postojeći nesklad „predstavlja najteže probleme tih gradova”. ${ }^{11}$ Vidljivo je to iz procijenjene optimalne površine po učeniku, koja je iznosila 2 $\mathrm{m}^{2}$. U Hrvatskoj je 1956. površina po učeniku iznosila manje od jednoga kvadratnog metra $\left(0,94 \mathrm{~m}^{2}\right) .{ }^{92}$ Nije bila rijetkost da su unutar jedne školske zgrade djelovale dvije i više škola. U većim gradovima ta je situacija bila i lošija, zbog čega su škole radile u dvije, tri, iznimno i više smjena. Osim za nastavne aktivnosti, školske zgrade koristile su se za brojne druge svrhe poput stambenih, administrativnih, kulturnih djelatnosti, socijalno-zdravstvenih, gospodarskih i dr. Higijenski uvjeti u školama također su bili problematični jer je tek 60,2\% školskih zgrada bilo spojeno na gradske vodovode. ${ }^{93}$ Među glavnim uzrocima stihijskoga razvoja urbanih središta u ranoj fazi razvoja komunalne infrastrukture pedesetih godina izdvaja se nerazvijenost urbanističke djelatnosti. Najlošija situacija bila je u naseljima gdje je prevladavala individualna izgradnja, nerijetko bespravna. Zbog ograničenih financijskih mogućnosti građana komunalna izgradnja u takvim naseljima bila je minimalna. Naselja s bespravnim objektima bila su nepravilnoga rasporeda, s uskim ulicama, često bez

89 SR-AJ-130-SIV, kut. 749, „Savez urbanista Jugoslavije Izvršnom vijeću Narodne skupštine FNRJ, 21. IX. 1956."

90 SR-AJ-142-SSRNJ, kut. 88, Socijalistički savez radnog naroda Jugoslavije, f. 142, „Stanbena zajednica kao urbanistički element planskog razvoja gradova i drugih naseljenih mesta”, str. 7.

91 SR-AJ-130-SIV, kut. 749, „Komunalno-stambena problematika, Druga skupština Stalne konferencije gradova i gradskih općina FNRJ. Saveznom izvršnom veću, 7. X. 1953. Maribor.”

92 Ukupna površina učionica podijeljena s ukupnim brojem učenika. Od većih hrvatskih gradova površina po učeniku iznosila je u Osijeku 0,63 $\mathrm{m}^{2}$, u Karlovcu i Splitu 0,54 $\mathrm{m}^{2}$, Zagrebu $0,59 \mathrm{~m}^{2}$ itd. SR-AJ-130-SIV, kut. 749, „Komunalno-stambena problematika, Stanje školskih zgrada i školskog prostora i materijalno financijska osnova škola u gradovima i industrijskim mestima /u 1956. godini/", str. 3-4.

93 Isto. 
nogostupa, nesređenoga kanalizacijskog sustava, što svjedoči o stihijskom karakteru njihova nastanka. Spomenute karakteristike takvih naselja odražavale su se na lošiju kvalitetu života stanovništva. ${ }^{94}$ Naselja individualne stambene izgradnje zauzimala su veće površine, izgradnja komunalne infrastrukture $u$ njima je bila skuplja, sa znatno manjim brojem stanovnika nego u naseljima kolektivnoga stanovanja, pa se takva praksa smatrala neracionalnim trošenjem prostora. ${ }^{95}$ Radi racionalizacije komunalnoga upravljanja osnivala su se specijalizirana tijela koja su građanima trebala osigurati bolju kvalitetu života. U smislu upravljanja i planiranja učinjen je iskorak reorganizacijom projektantske službe 1951., raspuštanjem državnih projektnih zavoda i formiranjem samostalnih projektnih organizacija s mobilnim timovima projektanata. ${ }^{96}$

Međutim, tek se s višim iznosima investicija u komunalnu izgradnju donekle uspijevalo zadovoljiti potrebu za osnovnom infrastrukturom u naseljima kolektivnoga stanovanja. Od 1953. do 1963. bilo je razdoblje stabilnoga razvoja Jugoslavije. ${ }^{97}$ Država je ostvarivala privredni uspon sa stopama rasta koje nisu zaostajale za zapadnim europskim zemljama, pa se veća sredstva usmjeravaju u savezne, republičke i općinske fondove za komunalne projekte. I pored znatna porasta investicija u komunalnoj djelatnosti, u drugoj polovini šezdesetih godina očekivalo se da će se ostvariti samo $50 \%$ planiranih investicija. ${ }^{98}$

Povećanje broja stanovnika i fizički rast gradova utjecali su na veće potrebe za boljom organizacijom mobilnosti stanovništva unutar gradova i između gradova i prigradskih prostora. ${ }^{99}$ Individualni promet rastao je paralelno sa standardom građana, posljedično i pritisak na postojeću prometnu infrastrukturu i parkirališna mjesta. Dinamika rasta prometne mreže može se pratiti preko ukupne dužine gradskih prometnica, asfaltiranih površina, izgradnje željeznica, tramvajskih pruga, broja brodskih linija u primorskim gradovima, gradnje zračnih luka i dr. ${ }^{100}$

Prema istraživanjima koja su sociolozi provodili sedamdesetih godina za potrebe urbanističkih zavoda, građani novih naselja očekivali su nakon zadovoljenja potreba za temeljnom komunalnom infrastrukturom da se grad

\footnotetext{
94 KLEMPIĆ, „Razvoj stambenih naselja Splita”, 111.

95 Isto.

96 DOMLJAN, „Poslijeratna arhitektura u Hrvatskoj”, 15.

97 SEFERAGIĆ, Kvaliteta života i nova stambena naselja, 77.

98 SR-AJ-130-SIV, kut. 749, „Stavovi Predsedništva stalne konferencije gradova Jugoslavije u pogledu kretanja cena komunalnih usluga i nekih pitanja daljeg razvoja komunalne privrede. Beograd, Jun 1968.", str. 1.

99 HR-DARI-78-NOKR, kut. 9, „Zapisnik”, 28. 2. 1959., „Zapisnik”, 4. 1. 1960., „Zapisnik”, 22.1. 1960., „Zapisnik”, 8. 7. 1960.

100 MAGAŠ, „Urbano geografska preobrazba Zadra”, 36.
} 
obogati kulturnim i rekreacijskim sadržajima. ${ }^{101}$ Urbani život zahtijevao je uz djelatnu komunalnu infrastrukturu koheziju i integraciju grada i društva. Posebno je bila važna adaptacija i integracija novoga, u pravilu ruralnog, stanovništva u urbano okruženje uz usvajanje odgovarajućih životnih praksi. Donošenjem generalnih urbanističkih planova uveden je red u urbani prostor te je smanjena stambena kriza i nekontrolirana gradnja.

\section{Demografske posljedice javnih politika}

Do sredine XX. stoljeća Hrvatska je bila dominantno ruralna zemlja sa slabo razvijenim urbanim središtima. Stupanj urbanizacije neke zemlje najčešće se određuje analizom udjela gradskoga u ukupnom stanovništvu. ${ }^{102}$ Neposredno nakon Drugoga svjetskog rata u gradovima je živjelo samo oko četvrtine stanovništva Hrvatske. ${ }^{103}$ Državne intervencije u industrijalizaciji, negativne politike prema selu, razlike u razvijenosti i načinu života u urbanim i ruralnim sredinama i inicirana snažna urbanizacija pokrenule su ruralno-urbane migracije. Kao osnovni pokazatelj demografske dinamike gradova koristi se promjena broja stanovnika u promatranom razdoblju 1948. - 1991. Najintenzivnije doseljavanje u gradove odvijalo se između 1961. i 1971 . godine. ${ }^{104} \mathrm{Na}$ demografska kretanja u priobalju utjecao je proces litoralizacije, tijekom kojega se u najveće obalne gradove poput Rijeke, Zadra i Splita doseljavalo stanovništvo iz zaleđa i s otoka. Broj stanovnika dominantno je rastao s imigracijom, koja je pozitivno utjecala i na prirodno kretanje stanovništva. Urbanizacija je bila polarizirana, pa su u migracijama manji i srednji gradovi najčešće zaobilaženi, a brzi populacijski rast imali su Zagreb, Split, Rijeka, Zadar i nešto manje Osijek. O dinamici useljavanja ponajbolje svjedoči primjer Zagreba. Tijekom sedamdesetih godina Zagreb je u prosjeku svake godine populacijski rastao za novih 15000 stanovnika. Mnoga naselja Hrvatske koja je državna statistika svrstavala u gradska nisu imala ukupan broj stanovnika koliko je Zagreb dobivao godišnje većinom useljavanjem. ${ }^{105}$ Novo područje useljavanja od šezdesetih godina postao je Južni Zagreb (od 1975. Novi Zagreb), koji je prema projekcijama trebao biti dom za 250000 stanovnika. ${ }^{106} \mathrm{Uz}$ pozitivne strane modernizacijskih politika u urbanim sredinama, višestruke su negativne posljedice. Prije svega dugoročno su nastali negativni gospodarski i demografski učinci na ruralne sredine. Tehnička i komunalna modernizacija u

101 HR-DAST-119-URBS, „Program za provedbeni urbanistički plan splitskog poluotoka. Sociološka studija. Split 1974.", str. 80.

102 VRESK, „Urbanizacija Hrvatske 1981-1991., 100.

103 FRIGANOVIĆ, „O demogeografskom procesu”, 100.

104 VRESK, „Neka obilježja urbanizacije SR Hrvatske”, 39.

105 SEFERAGIĆ, „Stanovanje kao pokazatelj socijalne segregacije”, 70.

106 Detaljno o izgradnji Novoga Zagreba vidi: GULIN ZRNIĆ, Kvartovska spika. 
ruralnim prostorima u pravilu je izostajala, pa su takve sredine ostajale bez preduvjeta da zadrže mladu populaciju, ostajući time bez najvažnijega razvojnog potencijala. Nadalje, urbanizacija je bila prostorno koncentrirana u najvećim središtima, što je ostavilo neravnomjerno razvijenu mrežu srednjih i manjih gradova. Pokazatelji demografske polarizacije Hrvatske su Zagreb, Split, Rijeka i Osijek, četiri makroregionalna središta, u kojima je 1991. živjelo više od četvrtine stanovništva Hrvatske, a samo u Gradu Zagrebu gotovo petina ukupne populacije države. ${ }^{107}$ Politike koje je kreirala država u svim su makroregionalnim središtima potaknule doseljavanje, koje je odigralo bitnu ulogu u populacijskoj dinamici tih gradova. U vrijeme završetka polustoljetne vlasti oblikovane jednopartijskim sustavom udio urbanoga stanovništva od četvrtine ukupne populacije postao je natpolovičan. ${ }^{108}$

\section{Zaključak}

U specifičnome hrvatskom kontekstu druge polovine XX. stoljeća javne politike usmjerene na modernizaciju urbanih sredina bile su oblikovane dominantno djelovanjem aktera koji su se svojim položajem i moći jasno izdvajali u procesu oblikovanja i donošenja legitimnih odluka od vrha prema nižim razinama, koje su ih provodile u djelo. Ono što ih izdvaja su moć, racionalan izbor i instrumentalno djelovanje. Zbog monopolističke uloge u odlučivanju i utjecaja u svim sferama života koje su imale KPJ i KPH tek je manji dio aktera izvan državnih, formalnih okvira mogao djelomično utjecati na formulacije i tijek provedbe nekih javnih politika. Ponajprije je riječ o stručnjacima različitih profesija i profesionalnih organizacija u socijalnim politikama, gdje njihovo djelovanje nije predstavljalo potencijalnu ugrozu autoritetu Partije i države. Napose se prostor djelovanja otvorio i proširio slabljenjem hijerarhijske kontrole osamdesetih godina, kada je ujedno vidljiva veća samostalnost aktera u javnim politikama. Procesi racionalizacije u odlučivanju postojali su i u socijalističkim sustavima, što omogućuje prostor za analizu različitih dimenzija javnih politika u interdisciplinarnoj perspektivi.

Hrvatski su gradovi u polustoljetnom razdoblju prošli znatne transformacije u industrijskom sektoru, izgradnji stambene, komunalne i prometne infrastrukture. Rastuće novo stanovništvo uglavnom je dolazilo iz ruralnih sredina i manjih, nerazvijenih gradova, čiji se razvojni potencijal ostvarivao u industrijski razvijenijim gradovima, koji su rasli fizički i demografski. Potrebu za stambenim prostorom vlasti nisu iskoristile samo za rješavanje stambenoga zbrinjavanja sve većega broja stanovnika, nego su stambene politike postale

107 NEJAŠMIĆ, TOSKIĆ, „Razmještaj stanovništva u Republici Hrvatskoj”, 97.

108 Model diferencijacije, 19. 
promotori društveno organiziranoga načina življenja u socijalističkom društvu. Jedno od obilježja socijalističke modernizacije snažna je institucionalizacija upravljanja gradovima i njihova planiranja. Dvostruki je značaj toga procesa: $s$ jedne strane vidljiva je ideološka potreba vlasti, ali i realnih okolnosti za rješavanje ekonomskih, socijalnih, komunalnih i ekoloških problema. Napose je kontrola planiranja gradova i upravljanja njima bila potrebna zbog nesklada između rastućega broja stambenih objekata u novim naseljima i nedostatne prateće komunalne infrastrukture.

Socijalistička modernizacija donijela je određene civilizacijske i ekonomske pomake vidljive u rastu obrazovanja, stambene, komunalne i društvene infrastrukture te životnoga standarda u urbanim područjima. Međutim, izostavila je brojne elemente razvoja, pa postoji i niz njezinih negativnih posljedica. Urbani sustav razvijao se nejednako, s polarizacijom upravnih, gospodarskih funkcija i stanovništva u najvećim gradovima, a manji i srednji gradovi su zaobilaženi, pa su posljedice takva razvoja vidljive i u današnjoj mreži urbanih naselja Hrvatske.

\section{Arhivski izvori}

HR-DARI-78-NOKR: Hrvatska, Državni arhiv u Rijeci, fond 78, Narodni odbor kotara Rijeka, Savjet za saobraćaj i pomorsku privredu.

HR-DAST-119-URBS: Hrvatska, Državni arhiv u Splitu, fond 119, Urbanistički zavod Dalmacije Split.

SR-AJ-41-SPK: Srbija, Arhiv Jugoslavije, Beograd, fond 41, Savezna planska komisija.

SR-AJ-60-KLPKP: Srbija, Arhiv Jugoslavije, Beograd, fond 60, Komitet za lokalnu privredu i komunalne poslove.

SR-AJ-130-SIV: Srbija, Arhiv Jugoslavije, Beograd, fond 130, Savezno izvršno veće.

SR-AJ-142-SSRNJ: Srbija, Arhiv Jugoslavije, Beograd, fond 142, kut. Socijalistički savez radnog naroda Jugoslavije.

\section{Objavljeni izvori i literatura}

ALFIREVIĆ, Đorđe; SIMONOVIĆ-ALFIREVIĆ, Sanja. „Urban housing experiments in Yugoslavia 1948-1970”. Spatium (2015), br. 34: 1-9. https://doi. org/10.2298/SPAT1534001A.

BASKIN, Mark. „Politički proces i policy zajednice u jugoslavenskoj migracijskoj politici”. Politička misao 24 (1987), br. 3: 43-56. 
BEŽOVAN, Gojko. „Stanovanje i stambena politika”. U: Socijalna politika Hrvatske, ur. Vlado Puljiz. Zagreb: Pravni fakultet Sveučilišta u Zagrebu, 2008, 337-389.

BILANDŽIĆ, Dušan. Historija Socijalističke Federativne Republike Jugoslavije. Glavni procesi 1918. - 1985. Zagreb: Školska knjiga, 1985.

BIRKLAND, Thomas A. An introduction to the policy process: theories, concepts, and models of public policy making. New York: Routledge, 2016.

BRKANIĆ, Ivana; ATANACKOVIĆ-JELIČIĆ, Jelena. „Socialist housing in Osijek". Electronic Journal of the Faculty of Civil Engineering Osijek-e-GFOS 9 (2018), br. 17: 1-10.

BUKVIĆ, Nenad. „Prilog povijesti institucija: Prezidijum Sabora Narodne Republike Hrvatske 1945. - 1953.” Arhivski vjesnik 60 (2017), br. 1: 61-88.

BUKVIĆ, Nenad. „Sabor Narodne Republike Hrvatske: organizacija i djelovanje (1945. - 1953.)”. Doktorska disertacija, Sveučilište u Zagrebu, Hrvatski studiji, 2017.

DAHRENDORF, Ralf. „The Strange Death of Socialism”. Studies: An Irish Quarterly Review 79 (1990), br. 313: 7-17.

DOLENEC, Danijela. „Preispitivanje ‘egalitarnog sindroma’ Josipa Županova”. Politička misao 51 (2014), br. 4: 41-64.

DOMLJAN, Žarko. „Poslijeratna arhitektura u Hrvatskoj”. Život umjetnosti 10 (1969): 3-45.

DURKHEIM, Émile. The Division of Labor in Society. New York: The Free Press, 1947.

FLERE, Sergej. „Da li je Titova država bila totalitarna?”. Političke perspektive 2 (2012), br. 2: 7-21.

FRANIĆ, Tin Sven; KORLAET, Luka; VRANIĆ, Dubravka. „Prilog analizi stambenih politika i planske stanogradnje Nizozemske i Hrvatske". Prostor: znanstveni časopis za arhitekturu i urbanizam 13 (2005), br. 2 (30): 195-204.

FRANKOVIĆ, Eugen. „Urbanističko planiranje Zagreba od 1945. do 1985." Radovi Instituta za povijest umjetnosti (1985), br. 9: 85-87.

FRIEDRICH, Carl J.; BRZEZINSKI, Zbigniew K. Totalitarian Dictatorship and Autocracy. New York: Praeger, 1956.

FRIGANOVIĆ, Mladen. „O demogeografskom procesu u (ne)urbanom prostoru SR Hrvatske”. Dela 6 (1989): 98-106.

GALJER, Jasna; GALIĆ, Anđela. „Kultura stanovanja u Zadru 1950-ih u kontekstu afirmacije modernizma”. Ars Adriatica (2017), br. 7: 313-328. 
GELO, Jakov. Demografske promjene u Hrvatskoj od 1780. do 1981. Zagreb: Globus, 1987.

GULIN ZRNIĆ, Valentina. Kvartovska spika. Značenja grada i urbani lokalizmi u Novom Zagrebu. Zagreb: Jesenski i Turk, 2009.

HEĐBELI, Živana; MOKROVIĆ, Nikola. „Pregled uprave u Hrvatskoj od 1945. do 1990. godine”. U: Tehnični in vsebinski problemi klasičnega in elektronskega arhiviranja. Materialno varstvo arhivskega gradiva [Elektronski vir]. Zbornik mednarodne konference (Radenci, 15. - 17. april 2015), ur. Nina Gostenčnik. Maribor: Pokrajinski arhiv Maribor, 2015, 207-222.

KARAMAN, Igor. Privreda i društvo Hrvatske u 19. stoljeću. Zagreb: Školska knjiga, 1972.

KARAMAN, Igor. „Uloga malog i srednjeg poduzetništva u oblikovanju kapitalističkog privrednog sustava na tlu Hrvatske”. Povijesni prilozi 9 (1990), br. 9: 1-36.

KLEMPIĆ, Sanja. „Razvoj stambenih naselja Splita nakon Drugog svjetskog rata”. Hrvatski geografski glasnik 66 (2004), br. 2: 95-119.

KOROV, Goran. „Zajednička ili zasebna? Paradigme u arhitekturi socijalističke Jugoslavije”. Kvartal: kronika povijesti umjetnosti u Hrvatskoj 9 (2012), br. 3-4: 48-56.

KRIŽIĆ ROBAN, Sandra. „Obilježja modernosti na području arhitekture, urbanizma i unutrašnjeg uređenja nakon drugoga svjetskog rata”. U: Socijalizam i modernost: umjetnost, kultura, politika 1950. - 1974., ur. Ljiljana Kolešnik. Zagreb: Muzej suvremene umjetnosti; Institut za povijest umjetnosti, 2012, 55-125.

KUKOČ, Višnja. „Razvoj Splita III od 1968. do 2009. godine”. Prostor: znanstveni časopis za arhitekturu i urbanizam 18 (2010), br. 1 (39): 166-177.

LASSWELL, Harold D. „The policy orientation”. U: The Policy Sciences: Recent Developments in Scope and Method, Daniel Lerner i Harold D. Lasswell, Stanford: Stanford University Press, 1951, 3-15.

LIPSET, Seymour M. Political man: the social bases of politics. New York: Doubleday, 1960.

MAGAŠ, Damir. „Urbano geografska preobrazba Zadra - Elementi prometnog sustava 1945.-1991." Geoadria 1 (1996), br. 1: 35-46.

MAROEVIĆ, Ivo. „Hrvatska arhitektura pedesetih. Kontinuitet Moderne u okruženju socijalizma”. Život umjetnosti 71-72 (2004): 141-145.

MERKEL, Wolfgang. Eine Einführung in die Theorie und Empirie der Transformationsforschung. Opladen: Leske + Budrich bei UTB, 1999. 
MIHALJEVIĆ, Josip. Komunizam i čovjek. Odnos vlasti i pojedinca u Hrvatskoj (1958. - 1972.). Zagreb: Hrvatski institut za povijest, 2016.

MIHALJEVIĆ, Josip. „Liberalizacija i razvoj medija u komunističkoj Hrvatskoj 1960-ih i na početku 1970-ih”. Društvena istraživanja 24 (2015), br. 2: 239-258.

Model diferencijacije urbanih, ruralnih i prijelaznih naselja u Republici Hrvatskoj. Metodološke upute 67. Zagreb: Državni zavod za statistiku, 2011.

NEJAŠMIĆ, Ivo; TOSKIĆ, Aleksandar. „Razmještaj stanovništva u Republici Hrvatskoj - dio općih demografskih i društveno-gospodarskih procesa”. Geoadria 5 (2000), br. 1: 93-104.

PERKOVIĆ JOVIĆ, Vesna; DUMANDŽIĆ, Frane. „Stambene zgrade arhitekta Frane Gotovca u Splitu 3". Prostor 19 (2011), br. 1 (41): 228-239.

PETAK, Zdravko. „Javne politike i problemi modernog upravljanja”. $\mathrm{Hr}$ vatska i komparativna javna uprava 8 (2008), br. 2: 443-462.

PETAK, Zdravko. „Javne politike: razvoj discipline u Hrvatskoj i svijetu”. U: Izlazak iz množine? Stanje hrvatske političke znanosti, ur. Mirjana Kasapović. Zagreb: Fakultet političkih znanosti, 2007, 187-215.

PETAK, Zdravko. „Komparativne javne politike: mogu li se uspoređivati rezultati djelovanja vlada?”. Politička misao 39 (2002), br. 1: 51-62.

PETAK, Zdravko; PETEK, Ana. „Dionici javnih politika”. U: Pojmovnik javnih politika, ur. Ana Petek i Krešimir Petković. Zagreb: Fakultet političkih znanosti, 2014, 47.

PETEK, Ana. „Akteri javnih politika”. U: Pojmovnik javnih politika, ur. Ana Petek i Krešimir Petković. Zagreb: Fakultet političkih znanosti, 2014, 23 24.

PETKOVIĆ, Krešimir. „Javne politike u povijesti časopisa Politička misao od 1964. do 2013: kako izgledamo u ogledalu poddiscipline?”. Politička misao 51 (2014), br. 1: 11-38.

PULJIZ, Vlado. „Socijalna politika i socijalne djelatnosti u Hrvatskoj u razdoblju 1900.-1960. godine". Ljetopis Studijskog centra socijalnog rada 13 (2006), br. 1: 7-28.

ROGIĆ, Ivan. Tehnika i samostalnost. Okvir za sliku treće hrvatske modernizacije. Zagreb: Hrvatska sveučilišna naklada, 2000.

ROGIĆ, Ivan. „Tri hrvatske modernizacije i uloga elita”. U: Upravljačke elite i modernizacija, ur. Drago Čengić i Ivan Rogić. Zagreb: Institut društvenih znanosti Ivo Pilar, 2001, 37-78. 
ROYCE, Edward. Classical Social Theory and Modern Society: Marx, Durkheim, Weber. Lanham; Boulder; New York; London: Rowman \& Littlefield, 2015.

RUSINOW, Dennison. „Understanding the Yugoslav Reforms”. The World Today 23 (1967), br. 2: 71-79.

SEFERAGIĆ, Dušica. Kvaliteta života i nova stambena naselja. Zagreb: Hrvatsko sociološko društvo, 1988.

SEFERAGIĆ, Dušica. „Stanovanje kao pokazatelj socijalne segregacije u zagrebačkom prostoru”. Sociologija sela (1975), br. 47-48: 73-81.

SMITH, David M. „The Socijalist City, Cities After Socialism”. U: Urban and Regional Change and Conflict in Post-Socialist Societies, ur. Gregory Andrusz, Michael Harloe, Ivan Szelenyi. Oxford: Cambridge, Blackwell, 1996, 70-99.

SOMERVILLE, Peter. „The social construction of home”. Journal of Architectural Planning and Research 14 (1997), br. 3: 226-245.

STIPEČ BRLIĆ, Gorana. „Neboderi - grad među oblacima”. Zbornik radova / Građevinski fakultet Sveučilišta u Rijeci 20 (2017), br. 1: 207-226.

ŠTAMBUK, Maja. „Selo i modernizacija: kratka povijest nesporazuma”. U: Prostor iza: kako modernizacija mijenja hrvatsko selo, ur. Maja Štambuk, Ivan Rogić i Anka Mišetić. Zagreb: Institut društvenih znanosti Ivo Pilar, 2002, 11-26.

ŠTAMBUK-ŠKALIĆ, Marina. „Prilog poznavanju institucija: Sabor Narodne Republike Hrvatske, saziv 1953-1963”. Arhivski vjesnik 45 (2002): 83102.

VRESK, Milan. „Neka obilježja urbanizacije SR Hrvatske 1981. godine”. Acta Geographica Croatica 17-18 (1982-1983), br. 1: 39-53.

VRESK, Milan. „Urbanizacija Hrvatske 1981-1991.: Osnovni indikatori stupnja, dinamike i karakteristika urbanizacije”. Geografski glasnik 54 (1992), br. 1: 99-115.

WAKEMAN, Rosemary. „Was There an Ideal Socialist City? Socialist New Towns as Modern Dreamscapes". U: Transnationalism and the German City. Studies in European Culture and History, ur. Jeffry Diefendorf i Janet Ward. New York: Palgrave Macmillan, 2014, 105-124.

ŽUPANOV, Josip. „Hrvatsko društvo danas - kontinuitet i promjena”. Politička misao 48 (2011), br. 3: 145-163.

ŽUPANOV, Josip. Od komunističkog pakla do divljeg kapitalizma: odabrane rasprave i eseji (1995. - 2001.). Zagreb: Hrvatska sveučilišna naklada, 2002. 


\section{SUMMARY}

\section{Modernization Processes in Croatia's Urban Living through the Prism of Housing and Communal Policies during the Era of Socialism}

This article points to the importance of several aspects of the 50 year-long modernisation process that brought industrial transformation and changes to the population structure in Croatia. The aim is to bring attention to the influence public policies (with their rationalised decision-making) had on this process using example cases of modernisation processes in housing and communal policies. The paternalistic role of the state, with its clear absence of plurality, became visible in every segment of economic, political, and social life. Due to the increased inflow of residents to the cities, the government paid great attention to housing and communal policies. The first measures for the rapid economic and social transformation of society came into effect early on, during the war period. Major state interventions were emphasised through industrialisation and urbanisation, which followed worker migrations from rural to urban areas. This paper also aims to warn about specific segments of political decision-making that have so far not been studied through the dimension of public policies, using the examples of some aspects of the modernisation of urban life in Croatia. In conclusion, the paper points to a possible interdisciplinary framework for research on the issue of public policies through a historical dimension.

Key words: modernisation; urbanisation; public policies; Croatia 